УдК $630 * 181.324$

\title{
СВОБОДНЫЕ АМИНОКИСЛОТЫ ВЕГЕТАТИВНЫХ ОРГАНОВ PICEA OBOVATA L. И PINUS SYLVESTRIS L.
}

\author{
(C) Е.В. Алаудинова“, П.В. Миронов \\ Сибирский государственный аэрокосмический университет, пр. Мира, 82, \\ Красноярск, 660049 (Россия), e-mail: alaudinovaev@yandex.ru
}

Показано, что смена фенологической фазы развития дерева, связанная с утратой морозоустойчивости и наступлением периода вегетации, сопровождается существенными изменениями состава свободных аминокислот в меристематических тканях почек Picea obovata L. и Pinus sylvestris L. Зимой у обеих пород вдвое по сравнению с весной повышен уровень непротеиногенных аминокислот. В то же время Picea obovata L. и Pinus sylvestris L. обнаруживают достоверные видоспецифичные различия по суммарному содержанию непротеиногенных аминокислот. При этом у Pinus sylvestris L. их доля в составе свободных аминокислот достигает 40\%, что вдвое выше, чем у Picea obovata L. B составе свободных аминокислот у Picea obovata L. и Pinus sylvestris L. запас азота находится в основном в виде глицина - 13 и 9\%, аргинина - 12 и 8\% и орнитина - 12 и 15\% соответственно. Помимо этого у Pinus sylvestris L. значимую роль в резервировании азота играет $\gamma$-аминомасляная кислота - около $19 \%$ и валин - около 6\%; у Picea obovata L. - лизин и глутаминовая кислота - около $10 \%$. В то же время содержание пролина - аминокислоты, с присутствием которой, как правило, согласована высокая низкотемпературная устойчивость растений, у исследованных морозоустойчивых хвойных пород невысокое - 0,04-0,34\%.

Весной при набухании почек у обеих пород возрастает доля аргинина и пролина и резко снижается - орнитина и $\gamma$-аминомасляной кислоты. Помимо указанных аминокислот у Picea obovata L. вдвое снижается содержание лизина. Для Pinus sylvestris L. весной характерно высокое содержание суммы аспарагиновой кислоты и аспарагина - 19\%; y Picea obovata L. повышено содержание аминокислот с короткой углеродной цепью - суммы серина и глицина - 22\%. В качестве надежного стрессового метаболита у обеих пород можно рассматривать орнитин, содержание которого в зимний период в меристемах почек 3-5 раз выше, чем весной в меристемах набухших почек.

Ключевые слова: Picea obovata L., Pinus sylvestris L., почки, меристемы, непротеиногенные аминокислоты.

\section{Введение}

Известно, что у морозоустойчивых хвойных пород Сибири в живых тканях зимующих почек белковый обмен имеет характерные особенности, связанные с уровнем содержания водорастворимого белка [1]. Например, лиственница сибирская, ель сибирская, пихта сибирская в расчете на абсолютно сухую ткань аккумулируют до 17-30\% водорастворимого белка, а сосна обыкновенная и сосна кедровая сибирская не более 2,5-3\%. Столь существенное отличие белкового обмена, безусловно, должно отразиться и на обмене свободных аминокислот - низкомолекулярных предшественников белков. Необходимо отметить, что сезонные изменения свободных аминокислот в различных органах и тканях хвойных изучались многими авторами [2, 3], но информация о свободных аминокислотах живых тканей почек до сих пор в научной литературе отсутствовала, что и явилось целью данной работы.

\footnotetext{
Алаудинова Елена Владимировна - профессор кафедры химической технологии древесины и биотехнологии, доктор биологических наук, тел. (3912) 27-36-54, e-mail: alaudinovaev@yandex.ru

Миронов Пётр Викторович - декан факультета переработки природных соединений, доктор химических наук, профессор, тел. (3912) 27-36-54, e-mail:mpv@sibstu.kts.ru
}

В качестве объектов исследования были выбраны ель сибирская и сосна обыкновенная - породы, характеризующиеся самым высоким и самым низким содержанием водорастворимого белка в зимний период. Сравнение состава свободных аминокислот в меристемах зимующих и набухших почек позволит выявить видовую специфичность или сходство по данному признаку; оценить сезон-

\footnotetext{
* Автор, с которым следует вести переписку.
} 
ную изменчивость и роль индивидуальных аминокислот как соединений, связывающих избыток азота, поступающего в растение и не используемого для синтеза стрессовых белков. Не менее важна и оценка накопления в зимний период свободных аминокислот, связанных с низкотемпературной устойчивостью.

\section{Экспериментальная часть}

Объекты исследования: ель сибирская (Picea obovata L.), семейство сосновые - Pinaceae; сосна обыкновенная (Pinus sylvestris L.), семейство сосновые - Pinaceae. Постоянные пробные площади расположены в Среднесибирском подтаежно-лесостепном районе на территории Мининского лесничества (смешанные древостои со сходными лесоводственно-таксационными характеристиками на серых среднеоподзоленных тяжелосуглинистых почвах).

Сбор образцов меристем производился, как описано ранее в работе [4], зимой в состоянии низкотемпературной устойчивости тканей и весной при утрате низкотемпературной устойчивости.

Свободные аминокислоты выделяли из водорастворимых веществ методом ионообменной хроматографии на колонке с катионитом КУ-2 [5] и анализировали с помощью автоматического анализатора аминокислот ААА-339 М.

В работе приводятся средние арифметические значения 3-5 аналитических повторностей экспериментов. Оценка значимости различий проведена методом сравнения средних значений по критерию Стьюдента при доверительной вероятности $P=0,95$.

\section{Обсуждение результатов}

В меристемах зимующих и набухших почек ели сибирской и сосны обыкновенной в различные периоды исследования обнаружено более 35 нингидрин-положительных соединений, среди которых достоверно идентифицированы 23 аминокислоты и два амида (табл.).

Свободные аминокислоты меристем ели сибирской и сосны обыкновенной, \% от а.с.т.

\begin{tabular}{|c|c|c|c|c|}
\hline \multirow{2}{*}{$\begin{array}{l}\text { Наименование } \\
\text { аминокислоты }\end{array}$} & \multicolumn{2}{|c|}{ Ель сибирская } & \multicolumn{2}{|c|}{ Сосна обыкновенная } \\
\hline & зимующие почки* & набухшие почки** & зимующие почки* & набухшие почки** \\
\hline Аспарагиновая & $0,28 \pm 0,01$ & $0,29 \pm 0,01$ & $0,15 \pm 0,01$ & $0,96 \pm 0,05$ \\
\hline Треонин & $0,24 \pm 0,01$ & $0,24 \pm 0,01$ & $0,08 \pm 0,01$ & $0,13 \pm 0,01$ \\
\hline Серин & $0,76 \pm 0,03$ & $0,75 \pm 0,02$ & $0,37 \pm 0,02$ & $0,99 \pm 0,05$ \\
\hline Аспарагин & $0,06 \pm 0,01$ & - & - & $0,98 \pm 0,05$ \\
\hline Глутаминовая & $0,96 \pm 0,03$ & $0,58 \pm 0,02$ & $0,44 \pm 0,02$ & $0,71 \pm 0,04$ \\
\hline Глутамин & $0,14 \pm 0,01$ & - & $0,04 \pm 0,01$ & - \\
\hline Пролин & $0,34 \pm 0,02$ & $0,53 \pm 0,02$ & $0,04 \pm 0,01$ & $0,22 \pm 0,01$ \\
\hline Глицин & $1,28 \pm 0,05$ & $0,78 \pm 0,03$ & $0,66 \pm 0,02$ & $1,02 \pm 0,05$ \\
\hline Аланин & $0,66 \pm 0,02$ & $0,37 \pm 0,02$ & $0,40 \pm 0,02$ & $0,56 \pm 0,03$ \\
\hline Цитрулин & - & $0,24 \pm 0,01$ & - & - \\
\hline$\alpha$-Аминомасляная & $0,06 \pm 0,01$ & - & - & - \\
\hline Валин & $0,06 \pm 0,01$ & - & $0,45 \pm 0,02$ & - \\
\hline Цистин & $0,24 \pm 0,01$ & $0,23 \pm 0,01$ & $0,09 \pm 0,01$ & $0,35 \pm 0,02$ \\
\hline Метионин & - & - & $0,08 \pm 0,01$ & - \\
\hline Цистатионин & $0,06 \pm 0,01$ & - & $0,04 \pm 0,01$ & - \\
\hline Изолейцин & $0,14 \pm 0,01$ & $0,20 \pm 0,01$ & $0,05 \pm 0,01$ & $0,12 \pm 0,01$ \\
\hline Лейцин & $0,21 \pm 0,01$ & $0,39 \pm 0,02$ & $0,18 \pm 0,01$ & $0,23 \pm 0,01$ \\
\hline Тирозин & $0,12 \pm 0,01$ & $0,12 \pm 0,01$ & $0,04 \pm 0,01$ & $0,08 \pm 0,01$ \\
\hline Фенилаланин & $0,09 \pm 0,01$ & $0,12 \pm 0,01$ & $0,12 \pm 0,01$ & $0,10 \pm 0,01$ \\
\hline$\beta$-Аланин & $0,05 \pm 0,01$ & - & $0,05 \pm 0,01$ & следы \\
\hline$\beta$-Аминомасляная & $0,05 \pm 0,01$ & - & $0,04 \pm 0,01$ & следы \\
\hline$\gamma$-Аминомасляная & $0,61 \pm 0,03$ & $0,21 \pm 0,01$ & $1,35 \pm 0,07$ & $0,71 \pm 0,03$ \\
\hline Орнитин & $1,17 \pm 0,05$ & $0,23 \pm 0,01$ & $1,06 \pm 0,04$ & $0,36 \pm 0,01$ \\
\hline Лизин & $1,04 \pm 0,03$ & $0,45 \pm 0,02$ & $0,54 \pm 0,03$ & $0,50 \pm 0,03$ \\
\hline Гистидин & $0,21 \pm 0,01$ & $0,17 \pm 0,01$ & $0,14 \pm 0,01$ & $0,17 \pm 0,01$ \\
\hline Аргинин & $1,16 \pm 0,05$ & $1,11 \pm 0,06$ & $0,59 \pm 0,03$ & $2,29 \pm 0,96$ \\
\hline
\end{tabular}

Примечание: * конец января; ** конец апреля. 
Существенную часть пула свободных аминокислот обеих пород составляли непротеиногенные аминокислоты: у ели - около 20\%, у сосны - около 40\% от суммы аминокислот. И у ели, и у сосны доля непротеиногенных аминокислот зимой вдвое превышала их содержание весной, подтверждая тем самым функцию этих низкомолекулярных соединений как стрессовых метаболитов, устраняющих избыток аммиачного азота в тканях [6]. Другим объяснением повышенного уровня непротеиногенных аминокислот является высокое содержание зимой общего белка, аккумулирующего протеиногенные аминокислоты. Уровень непротеиногенных аминокислот у сосны почти вдвое выше, чем у ели [7], т.е. значительная часть аминного азота у породы с низким содержанием водорастворимого белка зимой запасалась в форме непротеиногенных аминокислот.

Состав непротеиногенных аминокислот в покоящихся почках был более разнообразен (рис. 1). У ели присутствовало шесть индивидуальных компонентов. Доминировал орнитин с долей 58\% в составе непротеиногенных аминокислот. Также отмечалось повышенное содержание ГАМК - 30\%. У сосны идентифицировано пять непротеиногенных аминокислот, среди которых преобладала $\gamma$-аминомасляная кислота (ГАМК) - около 50\%, а доля орнитина составляла 39\%. При переходе от покоя к вегетации цистотионин, $\alpha$-аминомасляная, $\beta$-аминомасляная, $\beta$-аланин, присутствовавшие зимой у обеих пород в незначительном количестве, исчезали полностью; содержание орнитина и ГАМК в меристемах достоверно снижалось (см. таблицу). Одновременно доля ГАМК в составе непротеиногенных аминокислот у сосны немного увеличивалась, а орнитина - снижалась.

У ели доля ГАМК оставалась на прежнем уровне, орнитина - уменьшалась почти вдвое. В результате уровень их содержания в меристемах становился равнозначным, кроме того, в таком же количестве появлялся цитруллин. Появление в составе аминокислот у ели в апреле цитруллина свидетельствует об активации орнитинового цикла [8] в меристемах и связано с участием цитруллина в биосинтезе аргинина, в дальнейшем (в мае) аккумулирующегося у этой породы в составе водорастворимых белков [9]. В то же время у сосны значительное увеличение содержания аргинина весной также является доказательством функционирования орнитинового цикла. Тогда отсутствие цитруллина - промежуточного продукта образования протеиногенного аргинина из непротеиногенного орнитина - может объясняться более высокой активностью фермента аргининосукцинат-синтетазы, чем орнитин-карбомоилтрансферазы. В этом случае цитруллин не будет накапливаться, а сразу же превратится в аргининсукцинат и далее - в аргинин.

В общем составе свободных аминокислот повышенной концентрацией (более 9\%) выделялись несколько, доля остальных была значительно ниже. У ели в число первых входили: серин, глутаминовая кислота, глицин, орнитин, лизин и аргинин; у сосны - аспарагиновая кислота, серин, аспарагин, глицин, ГАМК, орнитин и аргинин. Суммарное содержание вышеперечисленных аминокислот составляло 56$79 \%$. Отдельно необходимо отметить значительное участие группы аминокислот, образующихся из продуктов фотосинтеза (серина + глицина + аланина) - 20-27\%, а также сравнительно невысокий процент участия аминокислот, происходящих из пирувата (лейцина + изолейцина + валина). У ели их доля -4 $8 \%$; у сосны - 3-9\%. В незначительном количестве (не более 1-2\%) у обеих пород зимой и весной присутствовали ароматические аминокислоты - фенилаланин и тирозин.

Аспарагиновая кислота, аспарагин, треонин и лизин входили в состав аспарагинового пула (рис. 2).

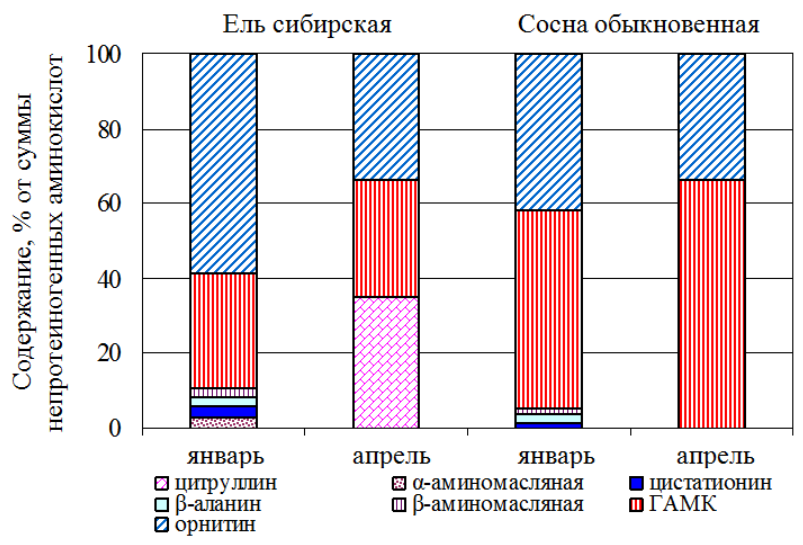

Рис. 1. Изменение состава непротеиногенных аминокислот

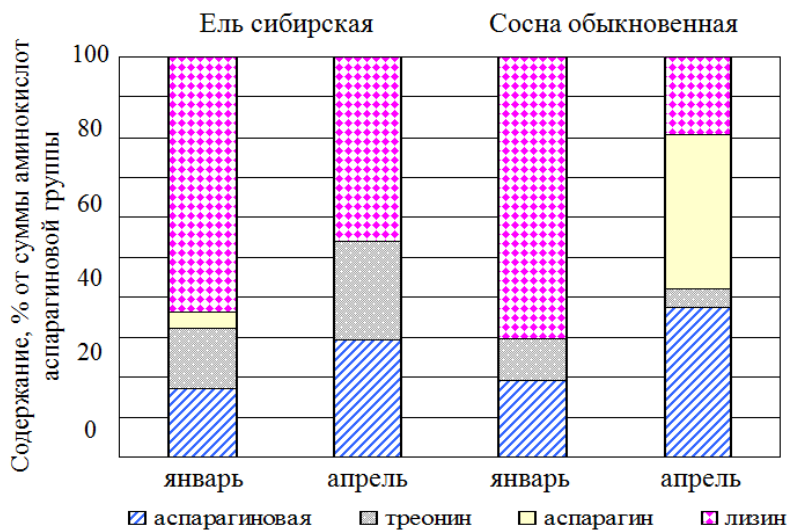

Рис. 2. Изменения состава аминокислот аспарагинового пула 
Зимой у обеих пород доминировал лизин, доля его участия в группе составляла 64-70\%. Известно, что лизин, обладая криозащитным действием в отношении клеточных мембран, накапливается при закаливании в вегетативных органах (корнях и листьях) озимой пшеницы [10]. В нашем случае повышенное (вдвое по сравнению с весной) содержание свободного лизина в меристемах зимой характерно только для ели (табл.). Вероятно, у этой породы в криозащите клеточных мембран участие лизина существенно, поскольку лизин входит в состав доминирующих аминокислот. У сосны уровень содержания лизина в меристемах в январе и апреле примерно одинаков и близок к весеннему уровню у ели. Интересно отметить, что весной в меристемах сосны появлялся аспарагин, а количество аспарагиновой кислоты увеличивалось почти на порядок (табл.). В результате соотношение аминокислот в группе аспарагиновой кислоты у этой породы изменялось в пользу последних. У ели столь значительных изменений не наблюдалось, а общая доля аспарагинового пула уменьшалась примерно на 15\% от зимнего уровня.

И у ели, и у сосны преобладали аминокислоты глутаминового пула - 37-50\%, в который входили глутаминовая кислота и ряд кислот, связанных с ней своим происхождением - глутамин, ГАМК, пролин, аргинин и его метаболические предшественники - цитруллин и орнитин (рис. 3).

При переходе дерева от состояния покоя к вегетации в этой группе аминокислот происходили наиболее сушественные изменения содержания и соотношения индивидуальных компонентов. В наименьшем количестве в глугаминовом пуле содержался глутамин, определявшийся у обеих пород исключительно в покоящихся почках. В наибольшем количестве в зимний период в составе глутаминового пула у ели и сосны присутствовали орнитин и аргинин. У сосны предпочтительно накапливался орнитин; у ели наблюдался примерно одинаковый уровень накопления обеих аминокислот. Весной характер количественных изменений аргинина и орнитина у обеих пород был сходен: содержание аргинина увеличивалось, а орнитина - снижалось.

Депонирование аминогрупп в составе аргинина и его метаболических предшественников орнитина и цитруллина связывают с аккумуляцией аммонийного азота, не используемого для синтеза стрессовых белков [11]. В тканях хвойных повышенный уровень их содержания рассматривается в качестве индикатора водного стресса [12]. Учитывая, что водосодержание меристем покоящихся почек ели и сосны в зимний период также значительно ниже, чем в период вегетации [13], вполне вероятно, что более высокий уровень накопления суммы аргинин + орнитин зимой может рассматриваться и в связи с водным дефицитом. Кроме того, известно, что аргинин в определенных условиях может замедлять гидролиз белков [10]. Поэтому относительно высокое его содержание в зимний период и в апреле, когда в Сибири еще возможны заморозки, будет способствовать защите белковых структур от повреждений.

Наиболее часто в литературе обсуждается роль ГАМК и пролина в связи с особенностями метаболизма растений в условиях действия низкотемпературного стрессового фактора. ГАМК в растительных организмах образуется путем декарбоксилирования глутаминовой кислоты ферментом глутаматдекарбоксилазой [8]. Это явление при различных видах стрессов, в том числе и низкотемпературном, зафиксировано у многих растений $[14,15]$. Предполагается, что ГАМК накапливается в тех растениях, у которых синтез белка замедлен, т.е. протеиногенная глутаминовая кислота активно не используется. Вероятно, этим и объясняется повышенный уровень ГАМК у сосны - породы, для которой в зимний период характерно более низкое содержание общего белка, за счет минимального уровня его содержания в цитозоле меристематических клеток. Показано, что, аккумулируясь в клетках, ГАМК оказывает на клеточные мембраны такое же защитное действие, как и пролин [10].

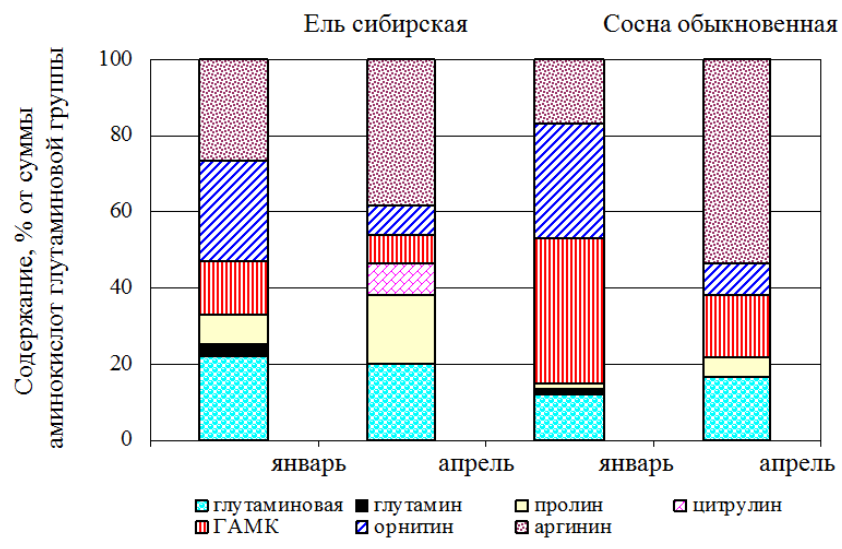

Рис. 3. Изменение состава аминокислот глутаминового пула 
ГАМК и глутаминовая кислота легко превращаются друг в друга. Это позволяет рассматривать ГАМК как запасный фонд глутамата. В настоящее время ГАМК отводится и роль соединения, поставляющего азот для синтетических процессов: она является донором аминогрупп и углеродного скелета при синтезе белка. Вследствие этого у пород, накапливающих водорастворимый белок при формировании криозащищенного состояния тканей, ГАМК расходуется, что и подтверждают наши исследования: у ели в зимующих почках уровень содержания ГАМК был в три раза ниже, чем у сосны, а уровень глутаминовой кислоты, напротив - выше примерно на 35\% (табл.). Одновременно в меристемах почек ели и сосны наблюдалось достоверно повышенное содержание ГАМК в зимний период по сравнению с весной (табл.). Интересно отметить, что при исследовании покоящихся почек различных видов березы наблюдалось близкое содержание ГАМК - 5-10\% от суммы аминокислот [16].

Криозащитные функции свободного пролина связывают с его специфическими физикохимическими свойствами [8]. Сегодня уже имеются подтверждения защитной роли пролина и при холодовом стрессе $[17,18]$. Показано, что в охлажденной воде пролин образует с ее молекулами прочные водородные связи, влияя на структуру образующихся кристаллов льда, оказывая, таким образом, защитное действие на клеточные мембраны. Однако в наших экспериментах повышенного уровня пролина в зимний период не обнаружено: у ели его содержание составляло около 3\%, а у сосны - менее $1 \%$. Весной уровень содержания пролина возрастал (табл.). Данный факт хорошо согласуется со снижением в апреле содержания пролина в составе водорастворимых белков [9]. Следовательно, в меристемах почек морозоустойчивых хвойных пород свободный пролин не может рассматриваться в качестве специфического стрессового метаболита при низкотемпературном воздействии.

\section{Выводы}

При смене фенологической фазы развития дерева, связанной с утратой низкотемпературной устойчивости и наступлением вегетационного периода в меристемах почек Picea obovata L. и Pinus sylvestris L., происходят существенные изменения содержания и состава свободных аминокислот:

- в меристемах зимующих почек обеих пород вдвое по сравнению с весной повышен уровень непротеиногенных аминокислот, при этом Picea obovata L. и Pinus sylvestris L. обнаруживали достоверные видоспецифичные различия по суммарному содержанию непротеиногенных аминокислот (у Pinus sylvestris L. содержание вдвое выше, чем у Picea obovata L.) и количественному соотношению их индивидуальных компонентов;

- в зимний период запас азота в составе свободных аминокислот у Picea obovata L. и Pinus sylvestris L. находился в основном в виде глицина, аргинина и орнитина; кроме того, у сосны значимую роль в резервировании азота играла ГАМК - 19,3\%, а у ели - лизин и глутаминовая кислота - около 10\%;

- Picea obovata L. в зимний период характеризовалась более высоким уровнем протеиногенных аминокислот (в первую очередь глутаминовой кислоты и глицина). У Pinus sylvestris L. на порядок выше, чем у Picea obovata L., была доля валина и в три раза выше доля непротеиногенной ГАМК;

- в криозащите клеточных мембран у Pinus sylvestris L. важная роль принадлежит ГАМК; у Picea obovata L. - лизину. Их содержание в меристемах зимой составляло 1-1,4\% от а.с.м. ткани, а весной снижалось вдвое. Вместе с тем содержание пролина - аминокислоты, с присутствием которой, как правило, согласована высокая низкотемпературная устойчивость растительных тканей, зимой у исследованных пород невысокое - 0,04-0,34\%;

- при набухании почек у обеих пород доля аргинина и пролина возрастала, а орнитина и ГАМК резко снижалась. Для Pinus sylvestris L. весной характерно высокое содержание аспарагиновой кислоты + аспарагина - 19\%; у Picea obovata L. повышено содержание аминокислот с короткой углеродной цепью серина + глицина $-22 \%$.

Таким образом, исследование и анализ свободных аминокислот позволил выявить сезонные и видоспецифические различия между Picea obovata L. и Pinus sylvestris L. по изучаемому признаку. Сезонные изменения хорошо согласованы с имеющимися в литературе сведениями о криозащитных функциях индивидуальных свободных аминокислот в растениях и видовыми особенностями метаболизма меристем, присущими морозоустойчивым хвойным видам с различной морфологией почек. В качестве надежного стрессового метаболита у ели и сосны можно рассматривать только орнитин, содержание которого зимой в меристемах почек 3-5 раз выше, чем весной. 


\section{Список литературы}

1. Alaudinova E.V., Simkina S.Yu., Mironov P.V. Water-Soluble Substances in Meristematic Bud of Picea obovata L. and Pinus sylvestris L.: Concenrations, Composition and Properties during the Development of Freezing Tolerance // Siberian Journal of Ecology. 2010. Vol. 17, N2. Pp. 327-333.

2. Судачкова Н.Е., Милютина И.Л., Семенова Г.П. Состав и содержание свободных аминокислот в различных частях и тканях Pinus sylvestris L., Larix sibirica Ledeb. и L. gmelinii (Rupr.) Rupr. // Paст. pecyрсы. 2003. T. 39. C. 19-31.

3. Чернобровкина Н.П. Экофизическая характеристика использования азота сосной обыкновенной. СПб., 2001. 175 с.

4. Алаудинова Е.В., Миронов П.В. Липиды меристем лесообразующих хвойных пород Центральной Сибири в условиях низкотемпературной адаптации 1. Характеристика состава жирных кислот фосфолипидов зимующих меристем Larix sibirica L., Picea obovata L. и Pinus sylvestris L. // Химия растительного сырья. 2009 . №2. C. $65-70$.

5. Кочетов Г.А. Практическое руководство по энзимологии. М., 1980. 272 с.

6. Судачкова Н.Е., Милютина И.Л., Романова Л.И. Влияние стрессовых воздействий в ризосфере на состав свободных аминокислот в тканях сосны обыкновенной // Физиология стресса. 2007. Т. 3, №2. С. 1-15.

7. Алаудинова Е.В. Экологические особенности низкотемпературной адаптации лесообразующих хвойных видов Сибири: структурно-химические изменения меристем почек: автореф. дисс. ... д-ра биол. наук. Красноярск, 2011. 36 с.

8. Гудвин Т., Мерсер Э. Введение в биохимию растений: в 2 т. М., 1986. Т. 1. 393 с.

9. Alaudinova E.V., Mironov P.V. Comparative characterctics of water-soluble proteins from Larix sibirica, Picea obovata and Abies sibirica Bud Meristems // Chemitry of Natural Compounds. 2010. Vol. 46, N3. Pp. 430-435.

10. Стаценко А.П. О криозащитной роли аминокислот в растениях // Физиол. и биохим. культур. раст. 1992. T. 24, №6. C. 560-564.

11. Liu J-H. Polyamines and their ability to provide environmental stress tolerance to plants // Plant Biotech. 2007. Vol. 24, N1. Pp. 117-126.

12. Sudachkova N.E., Milyutina I.L., Semenova G.P. Influence of water deficit on contents of carbohydrates and nitrogenous compounds in Pinus sylvestris L. and Larix sibirica Ledeb. tissues // Eurasian. J . For. Res. 2002. N4. Pp. 1-11.

13. Алаудинова Е.В., Симкина С.Ю., Миронов П.В. Сезонные изменения содержания воды в меристематических тканях почек Picea obovata L. и Pinus sylvestris L. и ее распределение в клетках // Хвойные бореальной зоны. 2007. №4-5. C. 487-491.

14. Bown A.W., Shelp B.J. The metabolism and function of gamma-aminobutyric acid // Plant Physiol. 1997. Vol. 115. N1. Pp. 1-5.

15. Satya N.V., Narayan V. Metabolism, enzymology and possible roles of 4-aminobutyrate in higher plants // Phytochemistry. 1990. Vol. 29, N2. Pp. 367-375.

16. Ветчинникова Л.В. Карельская береза и другие редкие представители рода Betula L. М., 2005. 269 с.

17. Gilmour S.J. Overexpression of the Arabidopsis CBF3 transcriptional activator mimics multiple biochemical changes associated with cold acclimation // Plant Physiol. 2000. Vol. 124, N4. Pp. 1854-1865.

18. Gleeson D., Lelu-Walter M.A., Parkinson M. Influence of exogenous proline on embriogenic cultures of larch (Larix leptoeuropaea Dengler), spruce (Picea sitchensis (Bong.) Carr.) and oak (Quercus robur L.) subjected to cold and salt stress // Ann. For. Sci. 2004. Vol. 61, N4. Pp. 125-128.

19. Стаценко А.П. О роли свободного пролина в криоадаптации озимых растений // Физиол. и биохим. культ. раст. 1994. Т. 26, №5. С. 509-512. 
Alaudinova E.V., Mironov P.V. FREE AMINO ACIDS IN VEGETATIVE ORGANS OF PICEA OBOVATA L. AND PINUS SYLVESTRIS L.

Siberian State Technological University, pr. Mira 82, Krasnoyarsk660049 (Russia), e-mail: alaudinovaev@yandex.ru

It is shown, that change of a phenological phase of development of the tree, connected with loss of frost resistance and coming of the period of vegetation, it is accompanied by considerable changes of structure of free amino acids in meristematic tissues of buds Picea obovata L. and Pinus sylvestris L.

In the winter at both species in comparison with spring level nonproteingeneous amino acids is doubled. During too time, Picea obovata L. And Pinus sylvestris L. show authentic specific distinctions under the total content nonproteingeneous amino acids. Thus at Pinus sylvestris L. their share as a part of free amino acids reaches $40 \%$, that twice above, than at Picea obovata L. As a part of free amino acids at Picea obovata L. and Pinus sylvestris L. the nitrogen deposit is mainly in a glycine - 13 and $9 \%$, arginine -12 and $8 \%$ and ornithine -12 and $15 \%$ accordingly. Besides it, at Pinus sylvestris L. significant role in nitrogen deposition play $\gamma$-aminobutyric acid - about $19 \%$ and valine - about 6\%; at Picea obovata L. - lysine and glutamic acid - on $10 \%$. During too time, the content proline - amino acids with which presence, as a rule, co-ordinated low temperature stability of plants, at the investigated cold-resistant coniferous species is low $-0,04-0,34 \%$.

In the spring at swelling of buds at both species as a part of free amino acids the share arginine and proline increases and sharply decreases - ornithine and $\gamma$-aminobutyric acids. Besides the pointed out amino acids at Picea obovata L. the content lysine twice decreases. For Pinus sylvestris L. the high content of the sum aspartic acids and asparagine $-19 \%$ in the spring is characteristic; at Picea obovata L. the content of the sum of amino acids with a short carbon chain - serine and glycine $22 \%$ is raised.

As reliable stressful metabolite at both species it is possible to consider ornithine, which content during the winter period in buds meristems of 3-5 times above, than in the spring in the swelling buds meristems.

Keywords: Picea obovata L., Pinus sylvestris L., buds, meristems, nonproteingeneous amino acids.

\section{References}

1. Alaudinova E.V., Simkina S.Yu., Mironov P.V. Siberian Journal of Ecology, 2010, vol. 17, no. 2, pp. 327-333.

2. Sudachkova N.E., Miliutina I.L., Semenova G.P. Rastitel'nye resursy, 2003, vol. 39, pp. 19-31. (in Russ.).

3. Chernobrovkina N.P. Ekofizicheskaia kharakteristika ispol'zovaniia azota sosnoi obyknovennoi. [Ecophysical characteristics of the use of nitrogen pine]. St. Petersburg, 2001, 175 p. (in Russ.).

4. Alaudinova E.V., Mironov P.V. Khimiia rastitel'nogo syr'ia, 2009, no. 2, pp. 65-70. (in Russ.).

5. Kochetov G.A. Prakticheskoe rukovodstvo po enzimologii. [Practical Guide to Enzymology]. Moscow, 1980, 272 p. (in Russ.).

6. Sudachkova N.E., Miliutina I.L., Romanova L.I. Fiziologiia stressa, 2007, vol. 3, no. 2, pp. 1-15. (in Russ.).

7. Alaudinova E.V. Ekologicheskie osobennosti nizkotemperaturnoi adaptatsii lesoobrazuiushchikh khvoinykh vidov Sibiri: strukturno-khimicheskie izmeneniia meristem pochek: avtoref. diss. ... d-ra biol. nauk. [Ecological features of low-temperature adaptation of forest-forming coniferous species of Siberia: structural and chemical changes in meristems of kidneys: the author's abstract of the dissertation of the Doctor of Biological Sciences]. Krasnoyarsk, 2011, 36 p. (in Russ.).

8. Gudvin T., Merser E. Vvedenie v biokhimiiu rastenii. [Introduction to plant biochemistry]. In 2 vol. Moscow, 1986, vol. 1, 393 p. (in Russ.).

9. Alaudinova E.V., Mironov P.V. Chemitry of Natural Compounds, 2010, vol. 46, no. 3, pp. 430-435.

10. Statsenko A.P. Fiziol. i biokhim. kul'tur. rast., 1992, vol. 24, no. 6, pp. 560-564. (in Russ.).

11. Liu J-H. Plant Biotech., 2007, vol. 24, no. 1, pp. 117-126.

12. Sudachkova N.E., Milyutina I.L., Semenova G.P. Eurasian. J. For. Res., 2002, no. 4, pp. 1-11.

13. Alaudinova E.V., Simkina S.Iu., Mironov P.V. Khvoinye boreal'noi zony, 2007, no. 4-5, pp. 487-491. (in Russ.).

14. Bown A.W., Shelp B.J. Plant Physiol., 1997, vol. 115, no. 1, pp. 1-5.

15. Satya N.V., Narayan V. Phytochemistry, 1990, vol. 29, no. 2, pp. 367-375.

16. Vetchinnikova L.V. Karel'skaia bereza i drugie redkie predstaviteli roda Betula L. [Karelian birch and other rare representatives of the genus Betula L.]. Moscow, 2005, 269 p. (in Russ.).

17. Gilmour S.J. Plant Physiol., 2000, vol. 124, no. 4, pp. 1854-1865.

18. Gleeson D., Lelu-Walter M.A., Parkinson M. Ann. For. Sci., 2004, vol. 61, no. 4, pp. 125-128.

19. Statsenko A.P. Fiziol. i biokhim. kul't. rast., 1994, vol. 26, no. 5, pp. 509-512. (in Russ.).

Received January 21, 2017

Revised March 5, 2017

\footnotetext{
* Corresponding author.
} 

